\title{
Time Series Aerial Photography Can Help Land Owners and Managers Understand Local Aspen Dynamics
}

\author{
By Eva K. Strand, M. Tess O'Sullivan, and Stephen C. Bunting
}

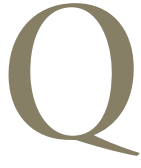

uaking aspen (Populus tremuloides) habitats contribute to species diversity, provide forage and shade for wildlife and livestock, and are highly valued by humans for their productivity and beauty. Aspen decline has been observed in the western United States over the past 50 years and has been mainly attributed to a decrease in fire frequency, caused by effective fire suppression. ${ }^{1}$ Changing fire regimes have allowed conifer species to expand into aspen stands. Another phenomenon, commonly referred to as "Sudden Aspen Decline" (SAD), has been observed within the past decade in the western mountains and in the Canadian aspen parklands. ${ }^{2}$ Mature aspen stems begin to die at rates beyond what is expected, which if aspen regeneration is limited, can eventually lead to the loss of the aspen roots and stands. Excessive browsing by livestock and wildlife can also inhibit aspen regeneration., ${ }^{3,4}$

To better comprehend the reasons for aspen decline in the semiarid western mountains, it is vital to understand a few facts about aspen biology. Aspen is a pioneer species. Although aspen produce an abundance of seeds that can establish and grow under wet conditions, it is now too dry in most areas of the West for aspen to reproduce via seed. Vegetative sprouting is thought to be the primary means of aspen regeneration. As a result, each individual stem in an aspen clone is a genetic copy of its parent stem. Recent research, however, indicates that genetic variability within aspen clones is common, suggesting that sexual reproduction in xeric aspen might occur more frequently than previously thought. ${ }^{5}$ Aspen stands in the western mountains commonly occur in conjunction with conifer species, but have also been observed as uneven-aged stands where aspen appears to persist as a stable, self-regenerating ecosystem. ${ }^{6}$ These stable aspen systems are unsuitable for conifers or are far away from conifer seed sources. ${ }^{7}$ In biophysical settings where aspen is seral to conifer species, slow-growing, shade-tolerant conifers begin to overtop aspen and eventually outcompete them, which can lead to aspen loss. ${ }^{8}$ Aspen growth rates are independent of conifer presence in early to midstand development; it is es- timated that conifers begin to out-compete aspen at a stand age of 100-150 years. ${ }^{8}$ An aspen stand that becomes dominated by conifer species can become permanently lost from the landscape. Landscape scale models indicate that mean fire intervals of 60-80 years keeps conifer species from eventually dominating aspen stands. ${ }^{9}$

"Sudden Aspen Decline" has been occurring over the past decade, causing death of mature aspen stems with no apparent regeneration in the form of suckering. Scientists and managers are currently researching the causes and working on finding solutions to this die-off, which currently affects as much as $10 \%$ of western aspen stands. A Colorado study documented that mature stands on south-facing slopes at low elevation are particularly susceptible to both disease and insects, primarily due to high temperatures and acute drought. ${ }^{10}$ Aspen appear susceptible to climatic change, but we don't know how aspen will respond to more severe fluctuations in temperature and precipitation predicted to occur as a result of global climate change. ${ }^{11}$

Browsing by wildlife and livestock can inhibit successful regeneration in aspen stands. ${ }^{3,4}$ Successful regeneration of aspen requires aspen sucker growth above the browse line, approximately $1.5 \mathrm{~m}$ for livestock and native ungulates. In a clipping experiment in California, aspen sucker growth was affected when as little as $20 \%$ of the terminal leaders were removed, with additional reduction in aspen sucker growth when a higher proportion of the terminal leaders were removed. ${ }^{4}$ Sucker growth was further reduced when browsing on terminal leaders was combined with removal of large portions of plant material such as leaves and stems. ${ }^{4}$ To encourage aspen regeneration, managers should minimize browse on terminal leaders, restrict midseason browsing over consecutive years, and avoid repeated browsing during the growing season. ${ }^{4}$ Herding, water/supplement redistribution, rest-rotation grazing, and seasonal grazing strategies are management techniques that can be applied across large landscapes to limit livestock browsing. ${ }^{4}$ Fencing can be used to eliminate browsing, but is an expensive option that is best suited for small-scale projects. 


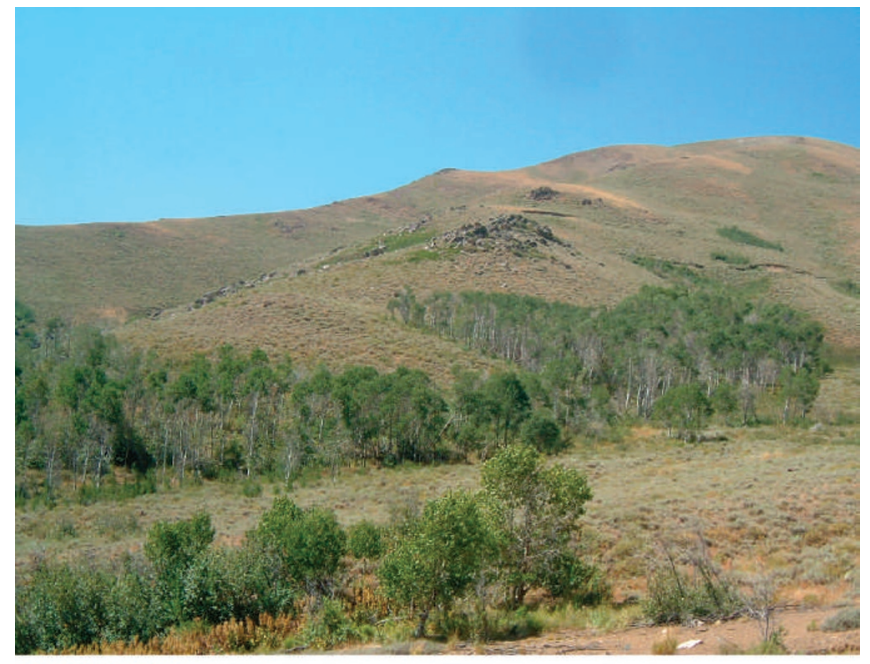

To sustain vibrant populations of aspen, landowners and managers need to find effective ways to monitor aspen persistence across the landscape. The overarching objective of this project was to detect change over time in aspen clone extent, stand structure, and conifer proportion, and to develop a remote monitoring methodology that could serve as a cost-effective decision-making tool for the aspen monitoring and management program at Lava Lake Land and Livestock (Lava Lake), a private company that runs a large domestic sheep operation across more than 340,000 ha in south-central Idaho. Key questions that led to this study were:

- How have aspens changed at a landscape scale over the last 30 years? Based on an understanding of aspen decline across the West, what is happening in the landscape around the Lava Lake operating area? Has there been a reduction in aspen clone extent?

- Can we detect changes at a watershed scale using remote sensing? Can remote sensing be a cost-effective way for Lava Lake to conduct monitoring?

- Can improvements in aspen condition be detected using remote sensing with a short time frame of five years?

\section{Lava Lake's Management Approach}

Lava Lake has made aspen habitat monitoring and improvement a priority because of their awareness of the importance of aspen habitat and region-wide reports of aspen decline. Since the company's inception in 2001, Lava Lake has operated with a mission to accomplish landscape-scale conservation while operating a working ranch. Lava Lake initiated its conservation efforts with an inventory and assessment of ecological condition across their operation. In 2002, less than $1 \%$ of the aspen habitat was in good or excellent condition, and the majority of the aspen stands were assessed to be in fair condition. ${ }^{12}$ Factors leading to the fair condition classification, rather than good or excellent condition, were low

Figure 1. The aspen stand in the upper photo is located at the lower, drier end of the Pioneer Mountain foothills where the precipitation is about $400 \mathrm{~mm}$ annually, typical of the Cottonwood/Crater allotment. The lower photo represents the higher precipitation zone where conifers are a common component in the aspen stands, typical of the Copper Creek watershed.

Table 1. Changes in grazing management at Lava Lake 2001 to 2006

\begin{tabular}{|c|c|c|c|c|}
\hline $\begin{array}{l}\text { Allotment/private } \\
\text { land unit }\end{array}$ & $\begin{array}{l}\text { Grazing use } \\
\text { pre-Lava Lake } \\
\text { ownership }\end{array}$ & $\begin{array}{l}\text { Date of initial } \\
\text { management } \\
\text { change }\end{array}$ & $\begin{array}{l}\text { Grazing use Lava } \\
\text { Lake ownership }\end{array}$ & Notes \\
\hline Cottonwood & $\begin{array}{l}\text { Cattle: summer- } \\
\text { fall use, } 200 \text { pair }\end{array}$ & Summer 2002 & $\begin{array}{l}\text { Cattle: } 100 \text { pair } \\
\text { from } 2002-2003 . \\
\text { Last season of use: } \\
2003 .\end{array}$ & $\begin{array}{l}\text { 2004-2006: no use. } \\
\text { Sheep use began in } \\
\text { Fall 2007. Four growing } \\
\text { seasons of rest. }\end{array}$ \\
\hline Copper Creek & $\begin{array}{l}\text { Sheep: } 5-6 \\
\text { bands/season }\end{array}$ & Spring 2002 & $\begin{array}{l}\text { Sheep: 2-3 bands/ } \\
\text { season }\end{array}$ & \\
\hline
\end{tabular}


regeneration, a high proportion of old trees, lack of diverse understory plants, and presence of compacted soils and/or bare ground. ${ }^{12}$ Aspen regeneration was low in the lower slope stands, whereas higher regeneration was observed at midand upper-slope areas. ${ }^{12}$

Lava Lake began implementing management changes across the operation in 2002. They made reductions in livestock use across the operation and changed from cattle grazing to sheep grazing in some areas. The reduction in numbers allowed for rest from grazing for portions of the range and fewer instances of repeated use during the growing season (Table 1). Lava Lake's grazing management is based on a multiyear grazing management plan and an extensive on-the-ground presence. Its management approach includes:
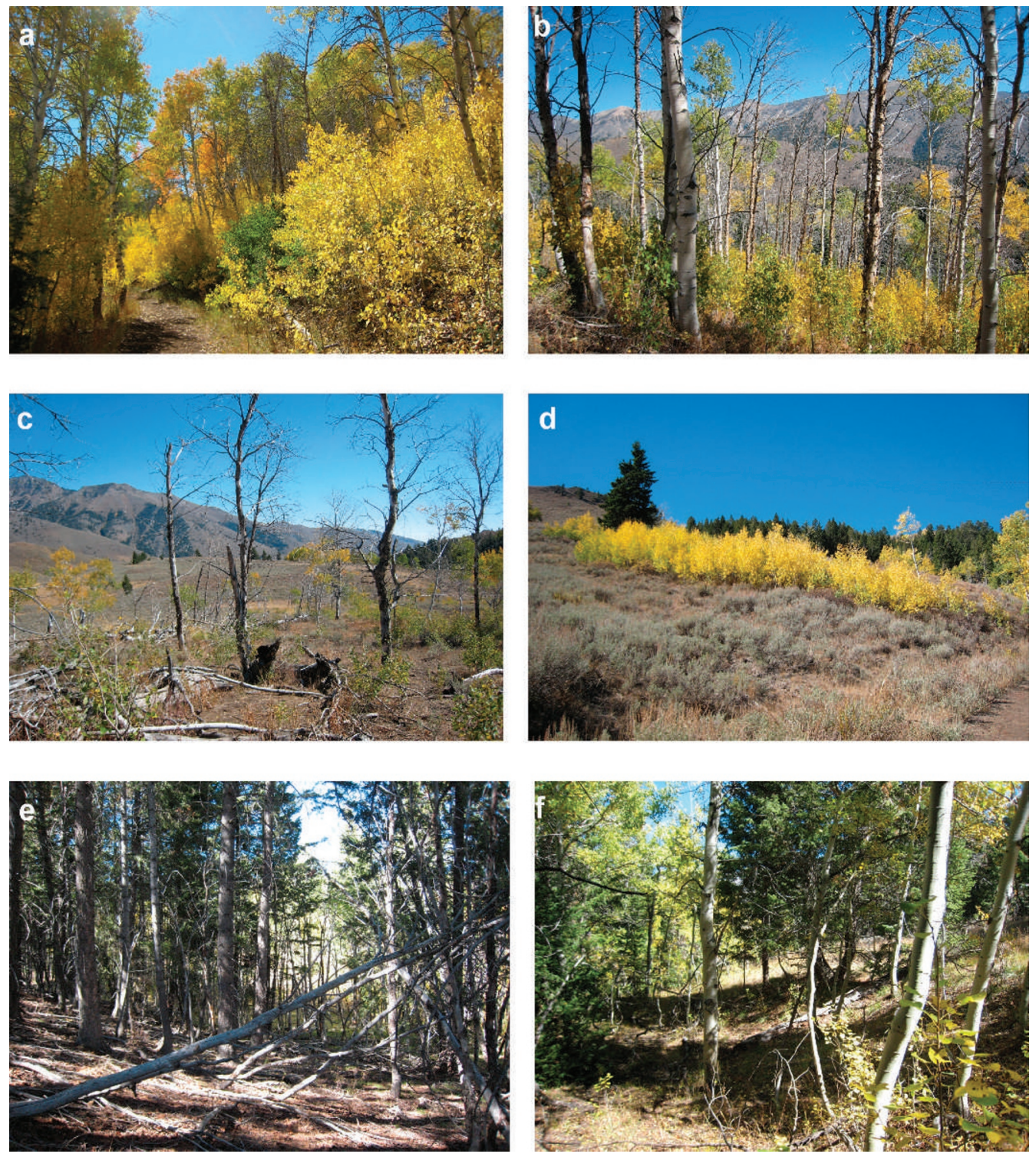

Figure 2. Aspen at Lava Lake and elsewhere occur in a variety of successional stages affected by disturbance events and land use legacy: a, aspen with regeneration, $\mathbf{b}$, dying overstory with regeneration, $\mathbf{c}$, dying overstory with poor regeneration, $\mathbf{d}$, stand initiation, e, aspen converted to conifer, and f, aspen/conifer mix.

- formalized annual grazing plans;

- regular training and education of sheep herders and supervisory staff to instill a stewardship-oriented perspective on land management and good relations with the public and land management agencies;

- implementation of a bonus system that rewards herders for good land stewardship;

- using a global positioning system (GPS) collar tracking system for sheep bands;

- regular and extensive field inspections by Lava Lake staff of grazing activities; and

- ecological monitoring, through photographic documentation and quantitative sampling of ecological conditions of sagebrush steppe, riparian, and aspen habitats in key portions of the grazed area.
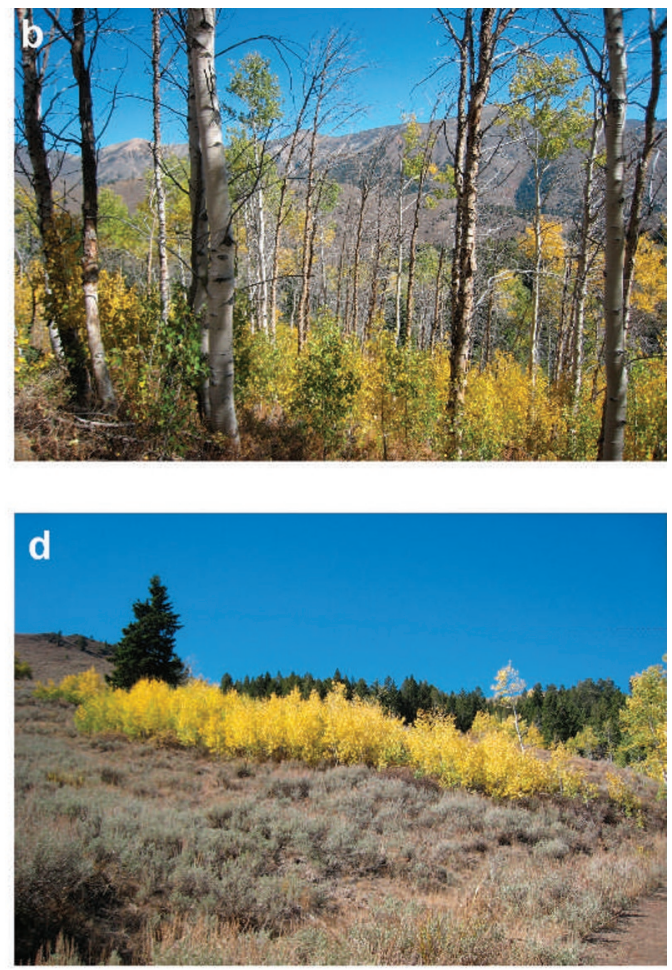

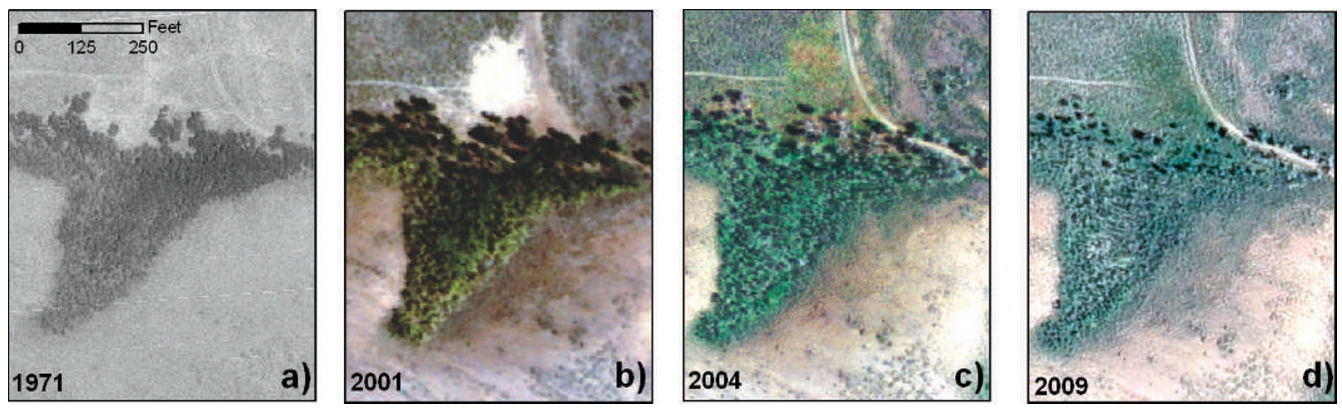

Figure 3. Aerial photographs of aspen stands in the Cottonwood/Craters allotment: a, Black and white photo from 1971. The extent of the aspen stand has been relatively stable over the past 40 years. b, Color photo from 2001. Notice the large bare area at the north end of the stand. This photo was acquired the same season as Figure 5a. c, Color photo from 2004. The north side of the stand is filling in with cheatgrass (see also Fig. 5b). d, Color photo from 2009. The north side of the stand is filling in with perennial grasses and regeneration is initiated in the aspen understory (see also Figs. $5 \mathrm{c}$ and $5 \mathrm{~d}$ ).

Initially, Lava Lake's management approach emphasized restoration through rest and reduced use. As sensitive areas such as aspen stands and riparian areas have recovered, it has allowed for more flexibility and for potential increases of use as habitat became more resilient.

Following the above management changes, Lava Lake managers noticed an overall improvement in aspen habitat conditions. The most notable change they saw was an increase in young aspen stems growing above browsing height, particularly in aspen stands on lower slopes that had previously been heavily used by livestock. At higher elevations, conifer encroachment into aspen continues. On drier sites, there is still concern about the potential to lose some stands based on low regeneration and low numbers of mature aspen trees.
To record these changes in a systematic manner, rather than relying on photographic documentation and anecdotal evidence, Lava Lake initiated an aspen field monitoring protocol in 2003. They established 34 transects in which regeneration, mature stem counts, and conifer presence were recorded, with a plan to reread the transects every 3-5 years. Although the field documentation provides detailed information on overstory and understory composition, Lava Lake management realized that it would be difficult to assess the condition of aspen across the landscape using field methods alone. Remote sensing provided the opportunity to assess not only a few select stands, but also to look at stands across the landscape and potentially provide a more complete and cost-effective analysis of their condition.

\section{Image Resources}

Satellite images from the Landsat sensor at a 30-m pixel size are available at no cost from the USGS Global Visualization Viewer.' Recent digital aerial photography is available from the Natural Resources Conservation Services (NRCS) Geospatial Data Gatewayii or from local data clearinghouses for individual states.iii Aerial photographs are available from as early as the 1930 s, and the earliest Landsat images available are from the 1970s. Historical photography is more challenging to find, but several archives exist, and digital copies of the photos are commonly available at a cost of \$20-40 per photo. The USGS Earth Explorer web site ${ }^{i v}$ provides search engines for a number of remote sensing data types through time. Photos are most commonly available in black and white, color, or color infrared. Most aerial photos taken prior to 2000 are black and white, but sometimes are in color infrared. Color infrared photos are taken with film that is sensitive to infrared light rather than visible light. Green vegetation (e.g., grass, shrubs, and trees) reflects highly in the infrared part of the light spectrum and appear as a bright red color in color infrared photos. Other sources of aerial photos are the National Archives or USGS National Map. Paper copies of historical photography are sometimes available in photo collections at libraries, historical societies, or county court houses. Fine-scale digital images (0.6-m pixels) can also be obtained from the QuickBird ${ }^{v}$ satellite sensor or from companies specializing in high-resolution aerial photography, for example Horizon Aerial Photography, Cloudstreet, and Aero-graphics. This type of data acquisition requires funding for acquisition and image processing resources. Historical imagery can also be viewed online for certain time periods at the public web site Google Earth.

' For information on the USGS Global Visualization Viewer, see http://glovis.usgs.gov.

ii For information on the NRCS Geospatial Digital Gateway, see http://datagateway.nrcs.usda.gov.

iii For example, http://inside.uidaho.edu for Idaho.

iv For information on the USGS Earth Explorer website, visit http://edcsns17.cr.usgs.gov/EarthExplorer/.

"To access Quickbird, visit http://www.digitalglobe.com.

vi To access Google Earth, visit http://earth.google.com. 


\section{Availability of Remotely Sensed Data}

Remotely sensed images are available from a number of sources at different scales, delivery formats, and color combinations, and can be categorized in two main groups: satellite images and aerial photographs. NASA satellite sensor Landsat and aerial photographs collected for the National Agriculture Imagery Program (NAIP) are image types that are readily available for use in the United States. These image types can be downloaded at no cost from the Internet.

\section{Integrating Field Monitoring with Remote Monitoring}

In 2007, Lava Lake initiated a collaborative project with the Department of Rangeland Ecology at the University of Idaho to explore methods for delineating and monitoring aspen stands using remote sensing technology. Two study areas within the Pioneer Mountains-Craters of the Moon landscape in southern Idaho were selected to serve as a pilot project: Cottonwood/Crater allotments (4,300 ha) in the sagebrush steppe (Artemisia spp.) and the Copper Creek watershed (7,200 ha) in sagebrush steppe with mixed conifer woodlands. The elevation of these sites ranges from 1,750 to $2,770 \mathrm{~m}$ in the Cottonwood/Crater allotment, and 1,890 to 3,000 $\mathrm{m}$ in the Copper Creek watershed. The area receives $400-900 \mathrm{~mm}$ of precipitation annually. Summers are hot and dry and the majority of precipitation falls as spring rain or winter snow. Aspen is an infrequent, yet critical component in this landscape dominated by semiarid sagebrush steppe (Fig. 1).

The Lava Lake project required the image format to be similar for historical (1970s) and current (2004 and 2009) images. Some of the aspen stands in the area are small $(<0.2$ ha), and relatively fine-scale imagery was required to identify aspen stands in the images. We used aerial photographs from NAIP because of the finer image resolution (1-2 $\mathrm{m})$, compared to Landsat satellite images $(30 \mathrm{~m})$. Photos available for the Pioneer Mountain-Craters of the Moon area are listed in Table 2.

Aspen stands are relatively easy to detect in NAIP aerial photographs of 1-m pixel resolution, particularly those stands that are located in the sagebrush steppe. Aspen can be difficult to differentiate from other broadleaf vegetation, such as chokecherry (Prunus virginiana) and willows (Salix spp.). Aspen stands becoming dominated by conifer forest can also be difficult to identify on aerial photos. Furthermore, aspen exist in a variety of stages affected by disturbance events and land use legacy, including: aspen with regeneration in the understory, dying overstory with regeneration, dying overstory with poor regeneration, stand initiation, aspen converted to conifer, and aspen/conifer mix (Fig. 2). Although the aspen stands are detectable on 1-m aerial imagery, field data are essential to correctly identify aspen structural stages, level of regeneration, and degree of conifer cover.

Field locations of aspen were recorded by Lava Lake using a handheld GPS unit with approximately 5-m accuracy. These sites were then superimposed over aerial photos in a
Table 2. Availability of aerial photographs for the study areas at Lava Lake. Images of different types and scales are available from different time periods and sources

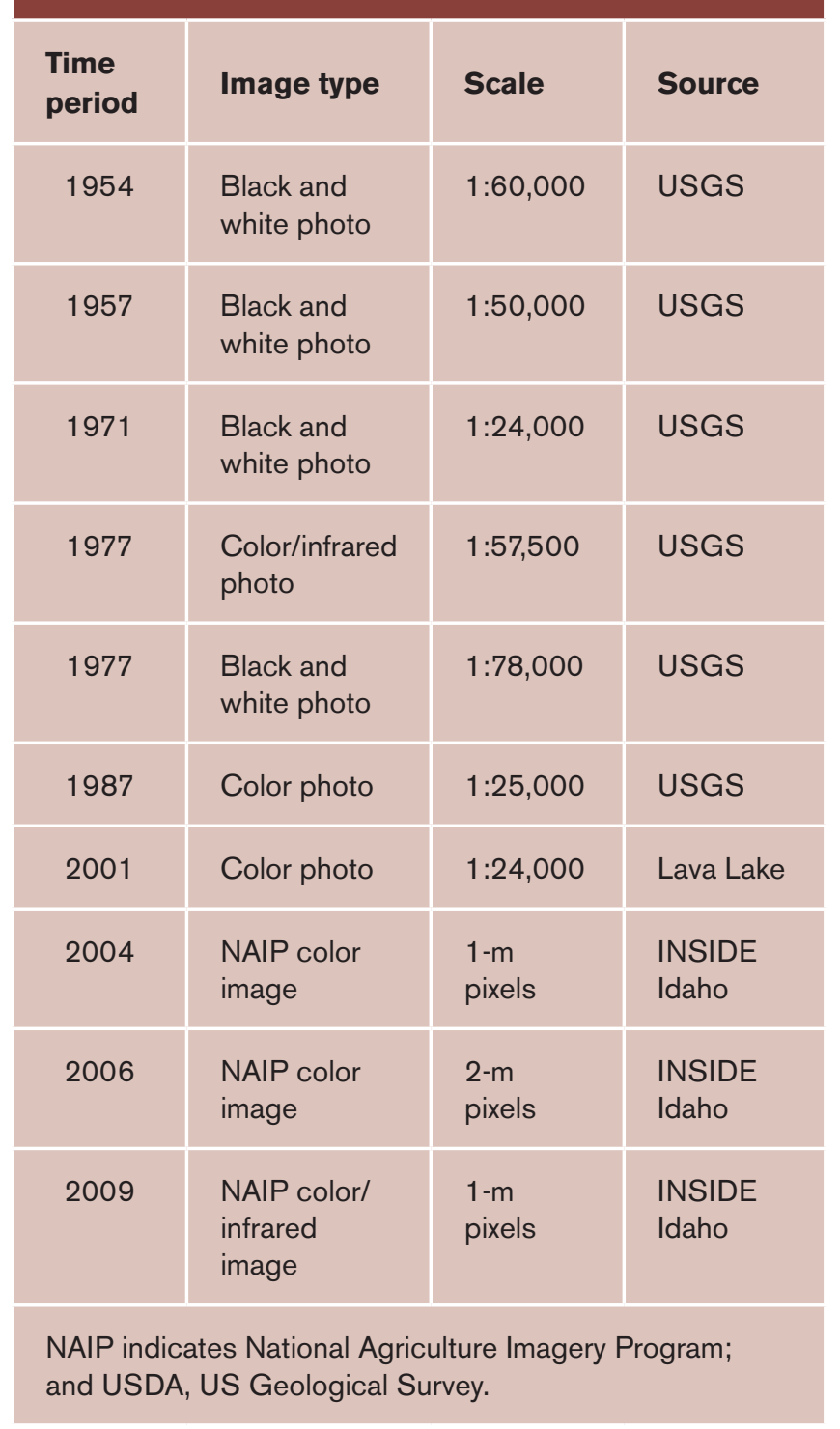

geographic information system (GIS) to connect field data and aerial photography. Additional aspen stands that were not visited on the ground could then be detected on the aerial image using ocular photo interpretation techniques.

\section{Delineating Aspen in GIS}

Aerial photographs from 2004 and 2009 (NAIP) were imported to a GIS. We used these images because they are georeferenced color photographs readily available at the INSIDE Idaho website. ${ }^{i}$ Aspen stands were delineated on the photos via ocular photo interpretation at a scale of 1:5,000 with a

i For information on INSIDE Idaho, see http://inside.uidaho.edu. 
Table 3. Characteristics of aspen stands delineated in the Cottonwood/Crater and Copper Creek management units

\begin{tabular}{|l|c|c|}
\hline Management unit & $\begin{array}{l}\text { Cottonwood/ } \\
\text { Crater }\end{array}$ & $\begin{array}{c}\text { Copper } \\
\text { Creek }\end{array}$ \\
\hline $\begin{array}{l}\text { No. of aspen stands } \\
\text { delineated }\end{array}$ & 50 & 144 \\
\hline $\begin{array}{l}\text { Area in riparian aspen } \\
\text { (ha) }\end{array}$ & 12 & 91 \\
\hline $\begin{array}{l}\text { Area in upland aspen } \\
\text { (ha) }\end{array}$ & 102 & 163 \\
\hline
\end{tabular}

minimum mapping unit of 0.1 ha. Upland aspen stands and riparian aspen stands were recorded separately. The photos from the 1970s were imported to the GIS and georegistered to the 2004 photos. Georegistration is the alignment of the 1970s photo to the coordinate system of the photos from 2004. This process can be tedious, particularly if there are several photos and if the photos are older, because camera and flight technology were less developed. The aspen stands delineated in the 2004 photo were then visually compared to stands in the 1970s and to 2009 photography. We compared:

1) Aerial extent of aspen stands from the 1970 s to 2004 by overlaying the georeferenced photos from the two time periods;

2) Percent overstory conifer within aspen stands in the $1970 \mathrm{~s}$ and 2004 (quantified into four classes: $<5 \%, 5-15 \%, 15-$ $30 \%$, and $30-50 \%$ cover);

3) Percent dead overstory aspen in the 1970s and 2004 (classified into five categories: $0 \%,<25 \%, 25-50 \%,>50 \%$, and $100 \%)$; and

4) Changes in aspen and green understory cover that has occurred between 2001 and 2009, using color photography. Changes that occurred between 2003/2004 and 2009 that can be attributed to modifications in livestock use were the primary focus.

In addition to manually delineating stands, we explored automated methods for identifying aspen stand structure at fine scale. These methods are based on identification of known aspen stands on the image and image analysis techniques to find areas with similar image characteristics. The accuracy of maps produced with this method yielded acceptable accuracy for a single time period, but using different types of images for different time periods resulted in high uncertainty.

\section{Landscape Level Changes, 1970s to 2004}

In the Cottonwood/Crater allotment and Copper Creek watershed, 194 aspen stands were delineated with stand sizes ranging from 0.1 to $15.9 \mathrm{ha}$. Of these aspen stands, 265 ha were located in the upland and 103 ha in the riparian zone (Table 3).

The aerial extent of aspen stands has generally not changed from the 1970s to 2004 (see examples in Figs. 3 and 4). No increase in dead aspen stems or conifer stems was detected in riparian stands, but there was an increase in dead aspen stems and conifer stems in upland aspen stands in the Copper Creek watershed (Table 4).

Aspen mortality and changes in conifer cover was difficult to interpret in the black and white images of 1971 for the Cottonwood/Crater allotments; thus, change detection for mortality and conifer cover was not conducted in this area.

\section{Landscape Level Changes, 2004 to 2009, Resulting From Altered Management}

At Lava Lake, improvements in both herbaceous productivity and aspen regeneration have been noticed by the managers since 2002. We investigated whether differences resulting from changes in grazing management could be detected when comparing images from 2004 to 2009. Stands with limited aspen regeneration and poor understory growth in 2001 were filling in with annual grasses in 2004 , and by 2008, perennial grass cover and aspen sucker

Table 4. Estimates of aspen mortality and increase in conifer cover in the Copper Creek management unit from the 1970 s to 2004 based on aerial photo interpretation

\begin{tabular}{l|c|}
\hline Type of change & $\begin{array}{c}\text { \% of stands } \\
\text { changed }\end{array}$ \\
\hline $\begin{array}{l}\text { No observed aspen mortality } \\
\text { Mortality in 25\% of the stand }\end{array}$ & 40 \\
\hline $\begin{array}{l}\text { Mortality in } 25-50 \% \text { of the stand } \\
\text { Mortality in }>50 \% \text { of the stand }\end{array}$ & 13 \\
\hline \begin{tabular}{l} 
No conifer cover in either time period \\
\hline periods
\end{tabular} & 47 \\
\hline $\begin{array}{l}\text { 5-15\% conifer cover in both time } \\
\text { periods }\end{array}$ & 15 \\
\hline $\begin{array}{l}\text { Increased conifer cover from } 0 \text { to } \\
<5 \%\end{array}$ & 13 \\
\hline $\begin{array}{l}\text { Increased conifer cover from }<5 \% \\
\text { to } 15 \%\end{array}$ & 24 \\
\hline
\end{tabular}


1970 s
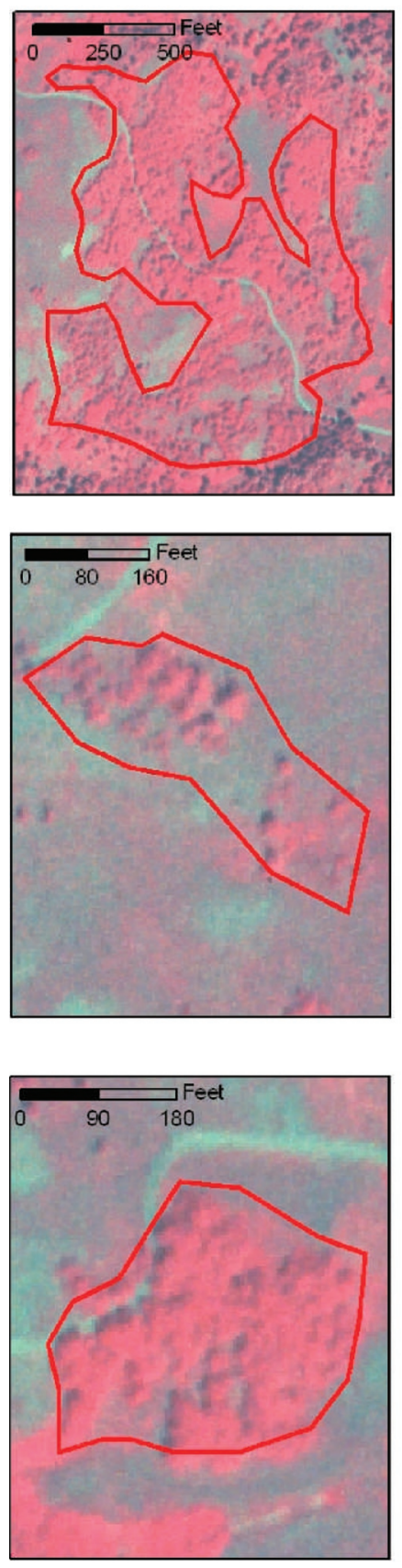

2004
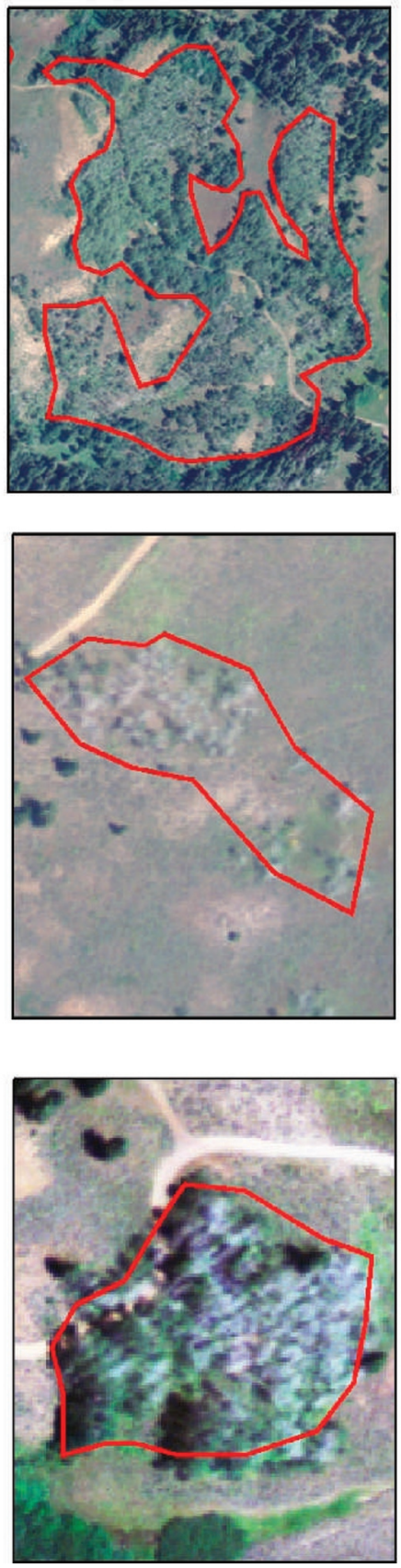

2009
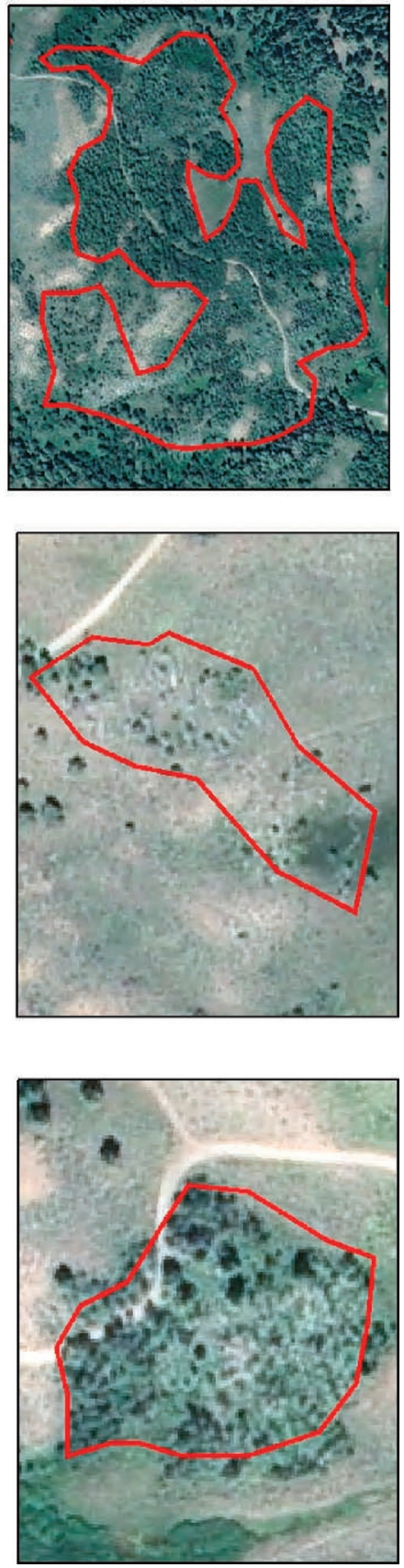

Figure 4. Three stands in the Copper Creek watershed. The extent of the stands has not changed over the past 30 years, whereas the structure of the aspen stands has changed. Mortality has occurred between 1977 and 2004 in many stands, but increased regeneration is observed in the 2009 imagery. The 1977 images were taken with an infrared camera; thus, the trees appear red rather than green.

counts were greatly improved (Fig. 5). Aerial photographs of the stand (Fig. 5) are shown for the years 1971, 2001, 2004, and 2009 in Figure 3. The extent of the aspen stand has not changed over the past 40 years. Notice the large bare area at the north side of the stand in 2001 (Fig. 3). The north side of the stand was filling in with cheatgrass (Bromus tectorum) in 2004, and by 2009 the north side of the stand was dominated by perennial grasses, and regen- eration had initiated in the aspen understory (Fig. 5d). The aspen stand in Figures 3 and 5 is one of many stands that have experienced substantial improvements in herbaceous cover and aspen regeneration since the change in management initiated in 2002. Some of these differences are already visible when comparing aerial photographs, but changes in overstory aspen cover will require a few more years before they can be detected remotely. 

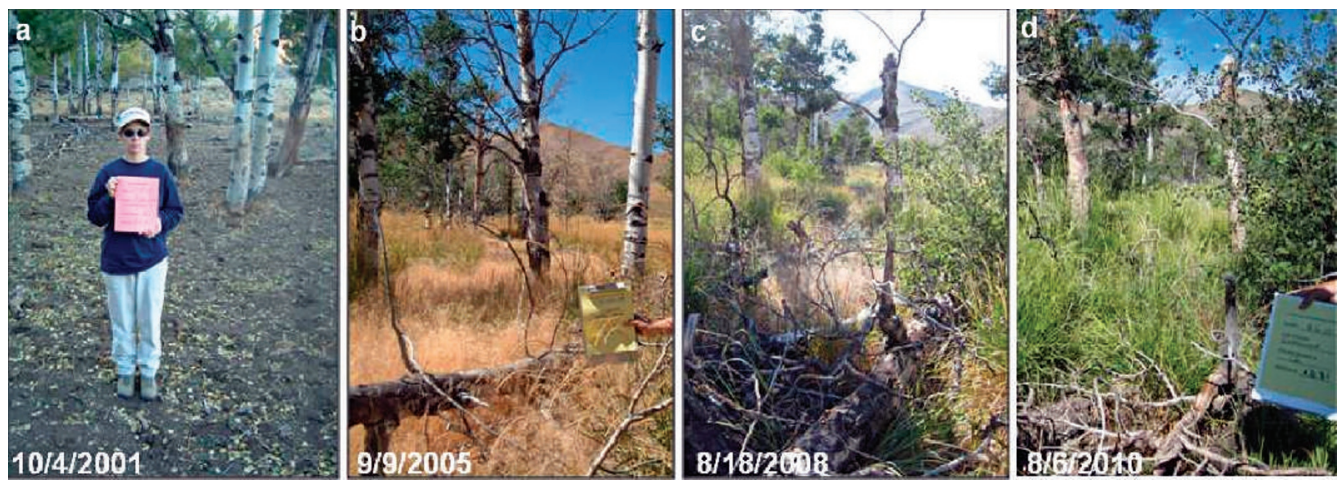

Figure 5. Noticeable changes have occurred in the several aspen stands since the livestock management was altered: a, The photo from 2001 was taken in an aspen stand in the Cottonwood/Craters allotment before the change in management strategy; b, In the photo from 2005 , grasses are beginning to occupy the site, and cheatgrass is dominating; $\mathbf{c}$ and $\mathbf{d}$, In 2008 and 2010, perennial grasses have outcompeted the cheatgrass, and aspen regeneration is visible in the background.

\section{Management Implications and Conclusions}

Delineation of aspen stands on aerial photos indicates that little or no change in aspen stand extent occurred from the 1970s to 2004 in the areas that we examined. We were able to observe the aspen extent using color, infrared, and black and white photography. Change in stand structure or conifer proportion within the stand was visible in the color and infrared aerial photographs, but was very difficult to see in the older black and white photographs. A comparison of long-term change in stand structure could therefore only be obtained in the Copper Creek watershed where infrared and color photography was available both in the 1970s and 2004. No increase in dead aspen stems or conifer stems were detected in riparian stands, but an increase in dead aspen stems and conifer stems was detected in upland aspen stands in Copper Creek.

We estimate that over $50 \%$ of the aspen area in the Copper Creek watershed is experiencing some level of overstory mortality, based on the photo interpretation of stands from the 1970 s to 2004 . Aspen mortality might be due to SAD, local conifer dominance, or a legacy of excessive grazing. Alternatively, the aspen stands might be undergoing a natural generation change in which young aspen stems replace the old and dying stems. Future remote and field monitoring will reveal if the alterations in grazing management are sufficient to boost aspen regeneration and restore aspen stands, or if the primary cause of mortality is drought-induced SAD. Conifer cover is slowly increasing in $30-40 \%$ of the stands in the Copper Creek watershed, a 5-10\% increase over 30 years.

In a shorter time frame, 2001 to 2009 , field reconnaissance was essential for monitoring changes in aspen regeneration and understory plant cover at Lava Lake. In several aspen stands, the changes noticed in the field were detectable on recent color aerial photographs. In particular, increased vegetation cover in the form of grasses or regenerating aspen at the edges of stands was possible to detect, whereas regeneration under a developed aspen canopy is more difficult to detect using aerial photographs.
There are many advantages to complementing field monitoring of aspen with remote monitoring. Remote sensing places the aspen stands in a landscape context and can assist in detecting an increase or decrease in vegetative cover within and around the aspen stands. The results from the remote sensing change detection can be helpful in prioritizing stands for on-the-ground assessments and monitoring. Assessments and monitoring can help land managers decide if management activities should be considered that could help maintain or improve aspen habitat conditions. Lava Lake will continue to monitor their aspen resources in the field, as well as using remotely sensed data. Field monitoring and remote sensing are complementary techniques; field monitoring provides insight about the understory conditions, including invasive species presence, plant diversity, forage production, current years utilization, and browsing pressure, whereas the remote sensing provides a landscape level overview of the aspen stand extent, overstory mortality, and tree cover.

It is important to consider a few methodological limitations in remote change detection of aspen. Aspen regeneration in the understory is difficult to assess from remotely sensed images. Aspen, broadleaf shrubs, dead aspen, and other senesced vegetation look very similar on a satellite image or aerial photo. The different photography types (black and white, color, and infrared) can complicate comparison of vegetation cover from one time period to another. In black and white photography, it can be challenging to differentiate between aspen and conifer trees, whereas this difference is straightforward in color and infrared photography. Georeferencing is another challenge, particularly for older aerial photos. Many of these challenges could be overcome if the images were acquired with a calibrated sensor such as QuickBird images (0.6-m pixel size), but these images are expensive and cannot be acquired retroactively. Landsat images can be calibrated and can provide important information, but the $30-\mathrm{m}$ pixel size did not provide the necessary detail for change detection of aspen at Lava Lake. 
The online availability of fine-scale NAIP data is expected to continue into the future and will provide Lava Lake and other land managers with an important tool for monitoring landscape-level change. Change detections such as the one conducted here can continue into the future by using the outlined aspen stands that were produced in this project.

\section{Acknowledgments}

This work was funded by a grant from the Lava Lake Institute for Science and Conservation and the High Meadows Foundation. We further thank Annie O'Sullivan for reviewing the manuscript. This publication is issued as Contribution No. 1072 of the Idaho Forest, Wildlife, and Range Experiment Station, University of Idaho, Moscow, ID.

\section{References}

1. Bartos, D. L. 2001. Landscape dynamics of aspen and conifer forests. In: Sustaining Aspen in Western Landscapes: Symposium Proceedings; 13-15 June 2000; Grand Junction, CO, USA. Fort Collins, CO, USA: USDA Forest Service Rocky Mountain Research Station. Proceedings RMRS-P-18. p. 5-14.

2. Frey, B. R., V. J. Lieffers, E. H. Hogg, and S. M. LandHAUSSER. 2004. Predicting landscape patterns of aspen dieback: mechanisms and knowledge gaps. Canadian Journal of Forest Research 34:1379-1390.

3. Bartos, D. L., And R. B. Campbell. 1998. Decline of quaking aspen in the interior West-examples from Utah. Rangelands 20(1):17-14.

4. Jones, B. E., D. F. Lile, and K. W. TAte. 2009. Effect of simulated browsing on aspen regeneration Implications for restoration. Rangeland Ecology Eं Management 62:557-563.

5. Mock, K. E., C. A. Rowe, M. B. Hooten, J. DeWoody, And V. D. Hipkins. 2008. Clonal dynamics in western North American aspen (Populus tremuloides). Molecular Ecology 17:4827-4844.
6. Rogers, P. C., A. J. Leffler, and R. J. Ryel. 2010. Landscape assessment of a stable aspen community in southern Utah, USA. Forest Ecology and Management 259:487-495.

7. Mueggler, W. F. 1989. Age distribution and reproduction of intermountain aspen stands. Western Journal of Applied Forestry 4:41-45.

8. Shepperd, W. D., D. L. Bartos, and S. A. Mata. 2001. Above- and below-ground effects of aspen clonal regeneration and succession to conifers. Canadian Journal of Forest Research 31:739-745.

9. Strand, E. K., L. A. Vierling, and S. C. Bunting. 2009. Landscape composition in aspen woodlands under various modeled management scenarios. Ecological Modelling 220:175-191.

10. Worall, J. J., L. Egeland, T. Eager, R. A. Mask, E. W. Johnson, P. A. Kemp, And W. D. Shepperd. 2008. Rapid mortality of Populus tremuloides in southwestern Colorado. Forest Ecology and Management 255:686-696.

11. Johnson, K. 2010. Killer of aspen slows, but worries about the beloved tree remain. New York Times, Science Section, October 18. Available at: http://www.nytimes.com/2010/10/19/ science/19aspen.html. Accessed 20 May 2012.

12. Rust, S. K., C. J. Murphy, C. L. Coulter, A. G. Tackett, AND G. B. EASDALE. 2001. Inventory and assessment of upland vegetation on the Pioneer Mountain Ranch. Boise, ID, USA: Conservation Data Center, Idaho Department of Fish and Game. 83 p.

Authors are Assistant Professor, evas@uidaho.edu (Strand) and Professor (Bunting), Dept of Forest, Rangeland, and Fire Sciences, University of Idaho, Moscow, ID 83844, USA; and Ecologist, Lava Lake Institute for Science and Conservation, Hailey, ID 83333, USA (O'Sullivan). 